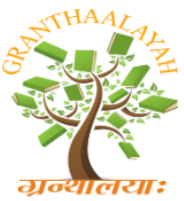

INTERNATIONAL JOURNAL OF RESEARCH GRANTHAALAYAH A knowledge Repository

Science

\title{
STUDY OF PHOTOVOLTAIC ENERGY STORAGES SYSTEM USING OF MAXIMUM POWER POINT TRACKING
}

\author{
Dr. S. K. Mahobia*1 \\ ${ }^{* 1}$ Assistant Professor, Department of physics, Rewa Engineering College, Rewa (M.P.), India
}

DOI: https://doi.org/10.29121/granthaalayah.v5.i2.2017.1711

\begin{abstract}
The uniform solar irradiation in the photovoltaic cells, power-voltage characteristics must be unique and the maximum powers are generated from PV cells. The MPPT Device are an essential part for photovoltaic power generation system. Maximum Power Point Tracking (MPPT) are used to optimize photovoltaic cells power.
\end{abstract}

Keywords: Photovoltaic Cells; Energy Storage System; MPPT.

CITE THIS ARTICLE: Dr. S. K. Mahobia (2017). "STUDY OF PHOTOVOLTAIC ENERGY STORAGES SYSTEM USING OF MAXIMUM POWER POINT TRACKING” International Journal of Research - Granthaalayah, 5(2), 119-121. 10.29121/granthaalayah.v5.i2.2017.1711.

\section{Introduction}

A solar cell converts sunlight into electrical power. Single crystal, polycrystal and amorphous silicon cells have been employed. The open type circuit voltage is about $0.5 \mathrm{~V}$ for mono- and polycrystal solar cell and $0.8 \mathrm{~V}$ for amorphous cells. Each cell can carry a current between 2 and 3 A. Each parallel branch is provided with a shunt diode in the way to avoid circulating currents. When a panel consisting of cells in series is used to charge a battery, a shunt diode is connected so that current never flows from the battery to the solar cells. By operating at maximum power points, the output of solar panels can be maximized or for a given power output, the cost of solar cells can be minimized. Therefore, drive is designed so that the solar panel operates at or close to maximum power points.

Photo-Voltaic Systems have become commercially successful during 1980s. The Solar PhotoVoltaic cells (PV cells) convert the incident solar light energy directly to electrical energy in DC form. The principles of solar energy, solar spectrum, flat plate collectors, parabolic through collectors with line focus etc. 


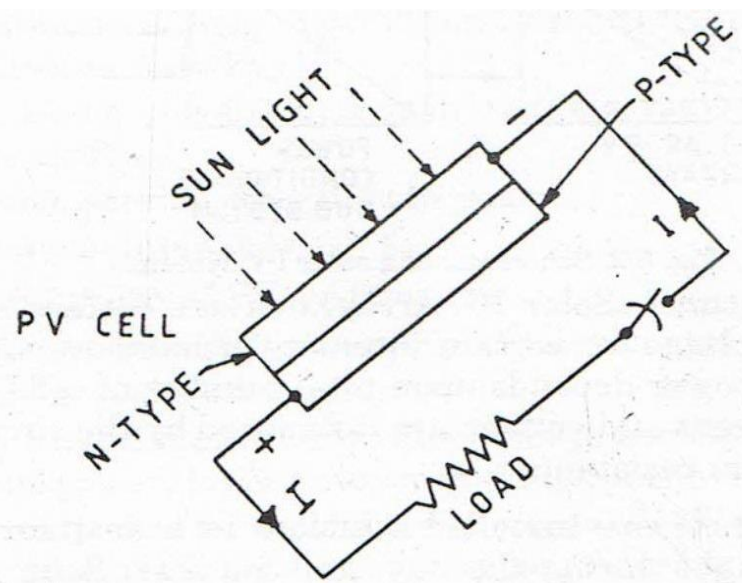

Figure 1: Schematic of a PV Cell

Many cells are connected in series/parallel to obtain desired voltage and power. Therefore problems of high temperature materials and excessive thermal loss are absent.

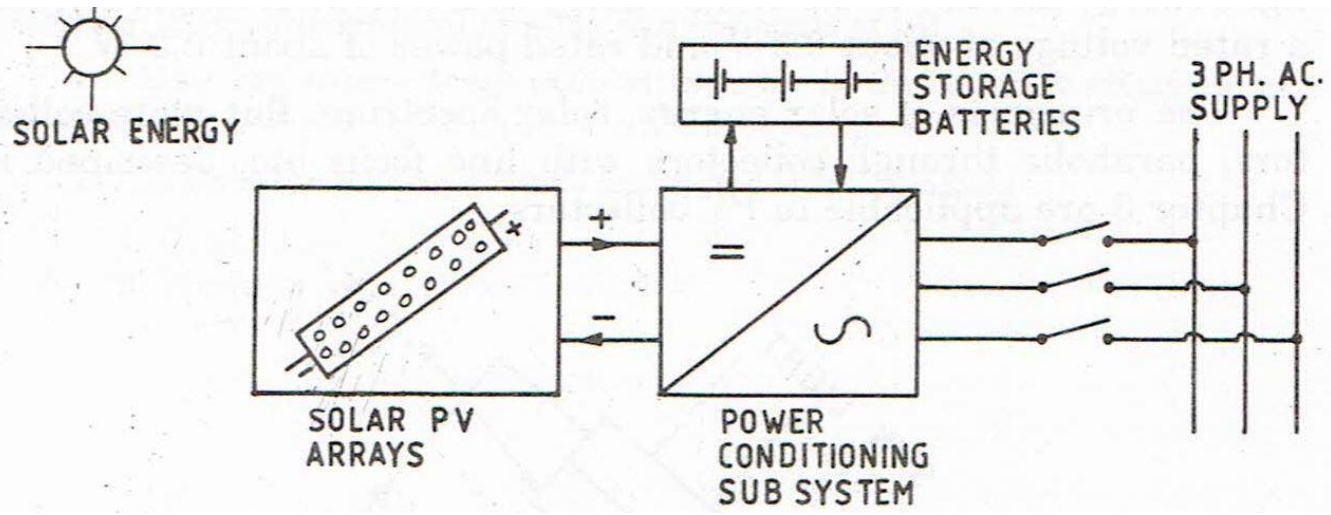

Figure 2: Schematic of a solar PV system

A Solar PV Array delivers certain DC current at certain DC voltage for certain intensity of incident solar energy. The current and voltage are influenced by the circuit connections and external resistance. Fixed type panels without focus are commonly used as they are simple, cheap and maintenance free.

\section{Result and Discussion}

Table 1: Voltage with respect to time using of Maximum Power Point tracking system

\begin{tabular}{|c|c|c|}
\hline Sr.No. & Time & Voltage in D.C. \\
\hline 1 & $10: 00$ & 10 \\
\hline 2 & $11: 00$ & 12 \\
\hline 3 & $12: 00$ & 15 \\
\hline 4 & $13: 00$ & 18 \\
\hline 5 & $14: 00$ & 17 \\
\hline 6 & $15: 00$ & 16 \\
\hline 7 & $16: 00$ & 12 \\
\hline 8 & $17: 00$ & 10 \\
\hline \hline
\end{tabular}




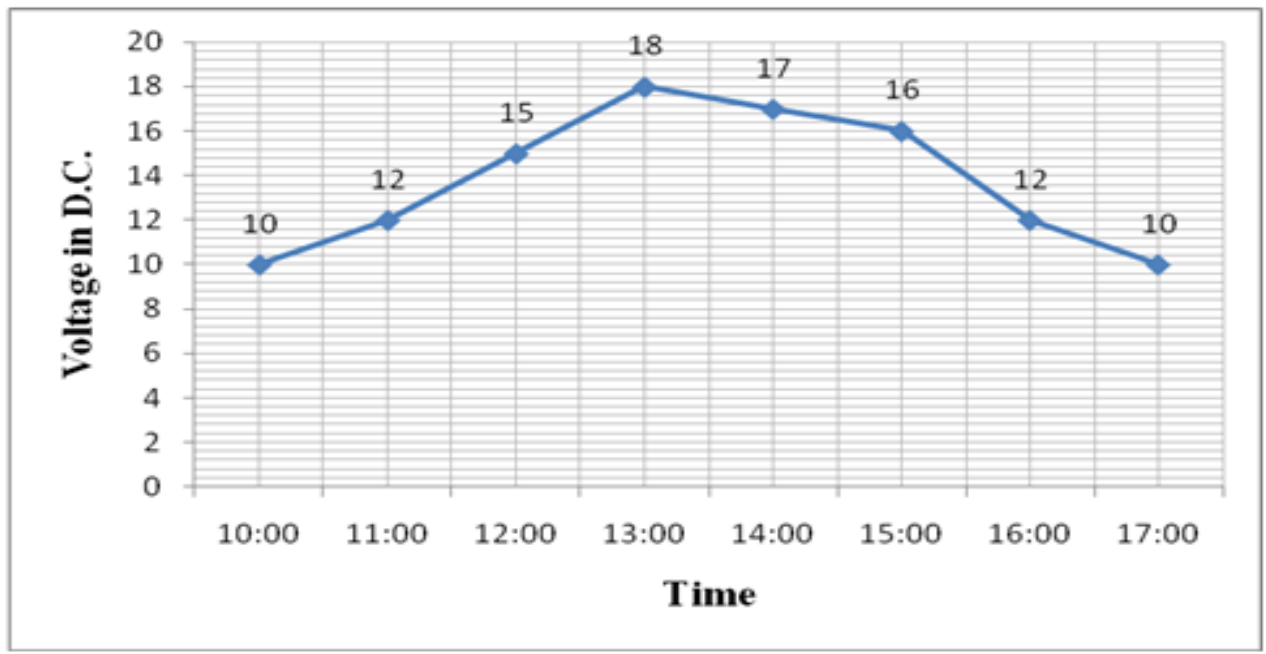

Figure 3: Voltage with respect to time using of Maximum Power Point tracking system

\section{Conclusion}

We are finding out the D.C. power by photovoltaic cells, the Maximum output voltages are $18 \mathrm{~V}$. D.C. At the time 13:00, which are shown in Table.1., output voltages are used for other devices.

\section{References}

[1] H. Serban, "A control strategy for a distributed power generation microgrid application with voltage and current-controlled source converter," IEEE Trans. Power Electron., vol. 25, no. 12, pp. 2981-2992, Dec. 2010.

[2] S. Thomas, and R. W. D. Doncker, "The balance of renewable sources and user demands in grids: Power electronics for modular battery energy storage systems," IEEE Trans. Power Electron., vol. 25, no. 12, pp. 3049-3056, Dec. 2010.

[3] T. Ise, "Low-voltage bipolar-type DC microgrid for super high quality distribution," IEEE Trans. Power Electron., vol. 25, no. 12, pp. 3066-3075, Dec. 2010.

[4] T. Bhattacharya,D. Tran, T. S. T. Siew, and A. M. Khambadkone, "Composite energy storage system involving battery and ultracapacitor with dynamic energymanagement inmicrogrid application,” IEEE Trans. Power Electron., vol. 26, no. 3, pp. 923-930, Mar. 2011.

[5] J. V. Paatero and P. D. Lund, "Impacts of energy storage in distribution grids with high penetration of photovoltaic power," Int. J. Distributed Energy Resources, vol. 3, no. 1, pp. 31-45, 2007.

[6] Y. Ueda, K. Kurokawa, T. Itou, K. Kitamura, K. Akanuma, M. Yokota, H. Sugihara, and A. Morimoto, "Performance analyses of battery integrated grid-connected residential PV systems," in Proc. 21st Eur. Photovolt. Sol. Energy Conf., 2006, pp. 2580-2584. 